\title{
Communal living: the role of polyploidy and syncytia in tissue biology
}

\author{
Nora G. Peterson • Donald T. Fox
}

Received: 14 April 2021 / Revised: 10 May 2021 / Accepted: 16 May 2021 / Published online: 1 June 2021

(C) The Author(s), under exclusive licence to Springer Nature B.V. 2021

\begin{abstract}
Multicellular organisms are composed of tissues with diverse cell sizes. Whether a tissue primarily consists of numerous, small cells as opposed to fewer, large cells can impact tissue development and function. The addition of nuclear genome copies within a common cytoplasm is a recurring strategy to manipulate cellular size within a tissue. Cells with more than two genomes can exist transiently, such as in developing germlines or embryos, or can be part of mature somatic tissues. Such nuclear collectives span multiple levels of organization, from mononuclear or binuclear polyploid cells to highly multinucleate structures known as syncytia. Here, we review the diversity of polyploid and syncytial tissues found throughout nature. We summarize current literature concerning tissue construction through syncytia and/ or polyploidy and speculate why one or both strategies are advantageous.
\end{abstract}

Keywords Polyploidy - Syncytia $\cdot$ Endocycle · Endomitosis $\cdot$ Fusion $\cdot$ Cyst $\cdot$ Multinucleate

Responsible Editor: Rachel O’Neill.

N. G. Peterson · D. T. Fox $(\bowtie)$

Department of Cell Biology, Duke University School

of Medicine, Durham, NC, USA

e-mail: don.fox@duke.edu

D. T. Fox

Department of Pharmacology and Cancer Biology, Duke University School of Medicine, Durham, NC, USA

\section{Overview}

In at least 9 different mammalian organ systems (Table 1), cells with greater than two genomes can be found. Focusing primarily on metazoans, this review focuses on such highly conserved increases in nuclear genome number and its impact on tissue biology. We discuss how nuclear genome number is increased and survey where cells with such increased genome content are found. We also broadly review our limited knowledge regarding how adding genomes can alter tissue function and speculate how future studies might tackle the largely unknown question of how extra nuclei impact tissue function. As part of this discussion, we compare and contrast the properties of large cells with extra genomes packed into a single nucleus versus those cells with multiple genomes in multiple nuclei.

\section{Under construction: adding genome copies to cells during tissue growth}

Diploid, sexually reproducing organisms pass on one set of chromosomes from each parent to their offspring. Cells in these organisms then grow and form tissues through mitotic cell cycles, whereby the diploid genome is fully replicated and the daughter cells wholly separate during mitosis and cytokinesis. But in specific tissues (for examples see Table1), the diploid genome can undergo further duplications to increase the total DNA content (C value) per cell (Fox 
Table 1 Nuclear number and ploidy and mechanism of various cell types

\begin{tabular}{|c|c|c|c|c|}
\hline Cell type (species) & Organ system & $\begin{array}{l}\text { Predominant nuclear } \\
\text { number and ploidy per } \\
\text { nucleus }(\mathrm{C})\end{array}$ & Mechanism & References \\
\hline $\begin{array}{l}\text { Germline cyst (female } \\
\text { mouse) }\end{array}$ & Reproductive & Up to $25 \times 1 C$ & Incomplete cytokinesis & (Lei and Spradling 2016) \\
\hline $\begin{array}{l}\text { Germline cyst (female } \\
\text { fruit fly) }\end{array}$ & Reproductive & $16 \times 1 \mathrm{C}$ & Incomplete cytokinesis & (Lei and Spradling 2016) \\
\hline Cardiomyocyte (pig) & Cardiovascular & $8 \times 2 C$ & Incomplete cytokinesis & (Velayutham et al. 2020) \\
\hline Cardiomyocyte (mouse) & Cardiovascular & $2 \times 2 \mathrm{C}$ & Incomplete cytokinesis & (Soonpaa et al. 1996) \\
\hline Cardiomyocyte (human) & Cardiovascular & $1 \times 4 \mathrm{C}$ and $2 \times 2 \mathrm{C}$ & $\begin{array}{l}\text { Incomplete cytokinesis or } \\
\text { endocycle }\end{array}$ & $\begin{array}{l}\text { (Brodsky et al. 1992; Hesse } \\
\text { et al. 2012; Mollova et al. } \\
\text { 2013; Bergmann et al. } \\
\text { 2015) }\end{array}$ \\
\hline Osteoclast (chicken) & Skeletal & $4 \times 2 \mathrm{C}$ & Cell-cell fusion & (Piper et al. 1992) \\
\hline $\begin{array}{l}\text { Macrophage granuloma } \\
\text { (human) }\end{array}$ & Lymphatic & $2 \times 2 \mathrm{C}$ and $1 \times 4 \mathrm{C}$ & $\begin{array}{l}\text { Incomplete cytokinesis or } \\
\text { endocycle }\end{array}$ & (Herrtwich et al. 2016) \\
\hline Myocyte (mouse) & Muscular & $\begin{array}{l}\sim 220 \times 2 \mathrm{C} \text { (extensor digi- } \\
\text { torum longus) }\end{array}$ & Cell-cell fusion & (Hansson et al. 2020) \\
\hline Myocyte (fruit fly) & Muscular & $\begin{array}{l}10-15 \times 32 \mathrm{C} \text { (ventral } \\
\text { longitudinal muscles } 3 \\
\text { and } 4)\end{array}$ & $\begin{array}{l}\text { Cell-cell fusion, endo- } \\
\text { cycle }\end{array}$ & (Windner et al. 2019) \\
\hline $\begin{array}{l}\text { Megakaryocyte (human, } \\
\text { rat) }\end{array}$ & Cardiovascular & $1 \times 8 \mathrm{C}, 1 \times 16 \mathrm{C}, 1 \times 32 \mathrm{C}$ & $\begin{array}{l}\text { Incomplete cytokinesis } \\
\text { and incomplete karyoki- } \\
\text { nesis }\end{array}$ & $\begin{array}{l}\text { (Odell et al. 1976; Brown } \\
\text { et al. 1997; Lordier et al. } \\
\text { 2008) }\end{array}$ \\
\hline Hepatocyte (human) & Digestive & $\begin{array}{l}1 \times 2 \mathrm{C}, 2 \times 2 \mathrm{C}, 2 \times 4 \mathrm{C} \\
1 \times 4 \mathrm{C}, 1 \times 8 \mathrm{C}\end{array}$ & $\begin{array}{l}\text { Incomplete cytokinesis } \\
\text { or endocycle }\end{array}$ & (Kudryavtsev et al. 1993) \\
\hline $\begin{array}{l}\text { Rectal papillar cells (fruit } \\
\text { fly) }\end{array}$ & Digestive & $100 \times 8 C$ & $\begin{array}{l}\text { Endocycle, cytoplasm- } \\
\text { sharing }\end{array}$ & $\begin{array}{l}\text { (Fox et al. 2010; Schoen- } \\
\text { felder et al. 2014; Peterson } \\
\text { et al. 2020) }\end{array}$ \\
\hline $\begin{array}{l}\text { Syncytiotrophoblast } \\
\text { (human) }\end{array}$ & Extraembryonic & up to $6 \times 10^{\wedge} 10 \times 2 \mathrm{C}$ & Cell-cell fusion & (Simpson et al. 1992) \\
\hline $\begin{array}{l}\text { Trophoblast giant cells } \\
\text { (mouse) }\end{array}$ & Extraembryonic & Up to $1 \times 512-1024 \mathrm{C}$ & Endocycle & $\begin{array}{l}\text { (Barlow and Sherman 1972; } \\
\text { MacAuley et al. 1998) }\end{array}$ \\
\hline Salivary gland (fruit fly) & Digestive & $1 \times 512-1024 \mathrm{C}$ & Endocycle & (Hammond and Laird 1985) \\
\hline $\begin{array}{l}\text { Subperineurial glia } \\
\text { (fruit fly) }\end{array}$ & Nervous & $1-4 \times 4-32 \mathrm{C}$ & $\begin{array}{l}\text { Incomplete cytokinesis } \\
\text { or endocycle }\end{array}$ & $\begin{array}{l}\text { (Unhavaithaya and Orr- } \\
\text { Weaver 2012; Von Stetina } \\
\text { et al. 2018) }\end{array}$ \\
\hline
\end{tabular}

and Duronio 2013; Øvrebø and Edgar 2018). Such cell cycle-dependent genome copy increases occur through two main processes. First, cells can switch from a mitotic cycle to a cycle commonly referred to as either the endocycle or the endoreduplication cycle. Endocycles consist of just one gap phase per cycle (known as G-phase) and an intervening genome duplication phase (S-phase), but no entry into mitosis. Endocycles lead to increased nuclear size and content within a single nucleus (Fig. 1). Examples of cells that undergo endocycles include the trophoblast giant cells in mammals and salivary gland and rectal papillar cells in insects (Table1). Second, mitotic cycling cells can switch to a cycle commonly known as endomitosis. Endomitosis involves truncating the cell cycle either in mitosis or cytokinesis and thus primarily differs from endocycles in that cells continue to at least enter mitosis. All endocycling cells, as well as any endomitotic cells that truncate mitosis prior to anaphase (incomplete karyokinesis), will yield mononucleated polyploid cells (Fig. 1). In contrast, endomitotic cells that progress to anaphase yet undergo incomplete cytokinesis will produce binucleate polyploid cells (Fig. 1), as occurs in many 
Fig. 1 Multiple mechanisms lead to the same ploidy and nuclear number outcomes. Cycles with absent or incomplete karyokinesis can both yield increased nuclear size and ploidy. Cycles with full nuclear division but incomplete cytokinesis, as well as cell-cell fusion, increase the number of nuclei. Each blue arrow represents a doubling in genome content. Each black arrow represents an incomplete cytokinesis. Each red arrow represents the addition of the number of single nuclei adjacent to the arrow. This illustration does not depict reductive division, which can reverse increased cellular ploidy

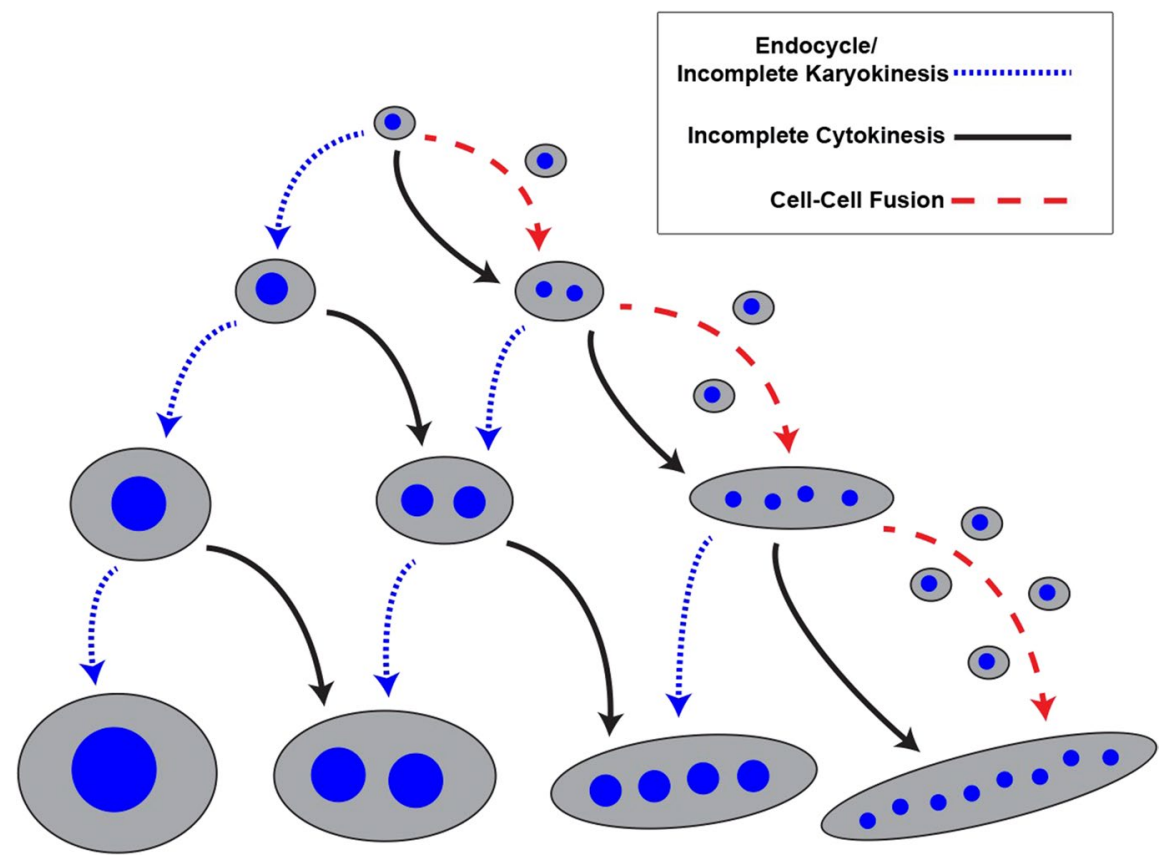

cardiomyocytes and hepatocytes (Table 1). Binucleate cells can also undergo subsequent endomitosis with incomplete cytokinesis to yield highly multinucleate syncytia (Fig. 1), as occurs in pig cardiomyocytes (Table1). For more information on regulation of the variant cell cycles that generate polyploid cells, we refer the reader to several recent reviews $(\varnothing v$ vreb $\varnothing$ and Edgar 2018; Shu et al. 2018; Lazzeri et al 2019; Lang and Schnittger 2020).

Independent of the cell cycle, fusion of plasma membranes of adjacent cells provides an additional mechanism to generate multinucleated cells and syncytia (Fig. 1). Examples of multinucleated syncytial tissues formed by plasma membrane fusion are skeletal myocytes, osteoclasts, and the syncytiotrophoblast (Table 1). Diverse cell fusion mechanisms include establishing competence for adjacent cells to recognize each other and fuse and the action of fusogen molecules and the actin cytoskeleton to remodel neighboring cell membranes. We refer the reader to these recent reviews (Hernandez and Podbilewicz 2017; Lee and Chen 2019; Petrany and Millay 2019) for a comprehensive discussion of cell fusion mechanisms and molecules. As highlighted in the sub-section "skeletal muscle," it is also possible for a tissue to increase genome copy numbers through a combination of both cell fusion and ploidy-increasing cell cycles.

The terminology surrounding cells with increased genome copy number can be confusing. Technically speaking, the product of endocycles, endomitosis, and cell fusion all produce polyploid cells. Polyploidy thus applies to multinucleated cells where each individual nucleus is diploid. However, as discussed in the sub-section "progenitor syncytia," some instances of increased nuclear content (e.g. germline cysts) are transient, and are therefore not typically referred to as polyploid. Similarly, binucleate cells are not commonly referred to as syncytia. To further add to the complexity, polyploid cells can continue to divide (Fox et al. 2010; Miyaoka et al. 2012), and polyploid cells can fuse/share cytoplasm (Peterson et al. 2020) and ploidy may also reduce in some cases (Duncan et al. 2010; Lucchetta and Ohlstein 2017; Matsumoto et al. 2021). For the purposes of this review, we use the term polyploid to refer to an increase in cellular DNA content to at least three or more genome copies, and similarly we use the term syncytia to refer to cells containing three or more nuclei. In the next two sections, we focus on the diversity and differing biology regarding ploidy states and nuclear number in animal tissues. 


\section{Distinct architecture: a survey of tissues with extra genomes across nature}

In this section, we present a survey of distinct examples of tissues with extra genomes, from mononucleate polyploid to highly multinucleated syncytia. We also discuss the potential benefits and tradeoffs of extra genomes in a number of tissues. A separate discussion of why tissues with extra genomes use different organizational strategies (e.g., mononucleate vs. multinucleated) is presented later, in the section "Form and Function."

Progenitor syncytia

During progenitor stages of development, nuclei of germ cells and early embryos frequently share cytoplasm. This sub-section highlights the conservation of syncytia in metazoan germ cell lineages and extraembryonic cells.

\section{Germline syncytia}

Nuclear division followed by incomplete cytokinesis (akin to endomitosis) is a widely conserved route to germline cyst formation in many animal species (Fig. 1; Table1; Fawcett et al. 1959; Hime et al. 1996; de Cuevas et al. 1997; Kloc et al. 2004; Maddox et al. 2005; Kosaka et al. 2007; Marlow and Mullins 2008; Lei and Spradling 2013; Amini et al. 2014). This process creates syncytial cyst structures in the female germline of fruit flies (Drosophila melanogaster), clawed frogs (Xenopus laevis), zebrafish (Danio rerio), and mice (Mus musculus). Within these cysts, organelles and other cytoplasmic materials can be shared (Zamboni and Gonndos 1968; Ruby et al. 1969; Gutzeit 1986; Bolívar et al. 2001; Pepling and Spradling 2001; Cox and Spradling 2003; Kloc et al. 2004; Kosaka et al. 2007; Marlow and Mullins 2008; Lei and Spradling 2013, 2016). Cyst cell number is invariantly 16 germ cells in female (and male) Drosophila germ cysts and can reach up to 25 cells in the mouse ovary (Lei and Spradling 2016, reviewed in Greenspan et al. 2015). Frequently, the oocyte is the only cell to survive through oogenesis, a phenomenon known as a meroistic ovary (McCall and Steller 1998; Foley and Cooley 1998 and reviewed in $\mathrm{Lu}$ et al. 2017). In such cases, syncytial organization can serve to nourish the growing oocyte.
However, nourishing of a future gamete cannot be the only function of germline syncytia.

For example, death of cyst cells supporting the future oocyte does not always occur in female syncytial germlines, such as in organisms with panoistic ovaries (reviewed in Lu et al. 2017). Similarly, while incomplete cytokinesis leads to syncytial cysts during male germ cell development in several species including in flies and mice, most nuclei of the cyst survive and eventually individualize into mature sperm (reviewed in Yoshida 2016; Yamashita 2018). As in the female syncytial germline, male syncytial germ nuclei can also share gene products (Braun et al. 1989; Caldwell and Handel 1991; Ventelä et al. 2003; Kaufman et al. 2020). Several models for why cytoplasm is shared in developing germ cysts where each germ cell goes on to become a gamete are outlined nicely in previous reviews (Greenbaum et al. 2011; Lu et al. 2017). Briefly, these include (1) the need to synchronize critical events in gamete production such as the onset of meiosis (which is highly synchronized in males), (2) the ability to neutralize a deleterious mutation in a single germ cell of the cyst that might otherwise outcompete neighboring gametes during fertilization, (3) the sharing of $\mathrm{X}$ and $\mathrm{Y}$ gene products to make early male gametes phenotypically diploid, and (4) increased sensitivity to DNA damage. More recently, study in C. elegans suggests that a syncytium can also compensate for the mechanical stress of oogenesis (Amini et al. 2014; Priti et al. 2018). Future study can determine the extent to which each of these mechanisms contributes to productive function of germline syncytia.

\section{Extra-embryonic syncytia}

A common theme across metazoan evolution is the syncytial nature of cells that support the growth of the embryo. Many insects have a syncytial yolk sac as part of the extra-embryonic tissue during embryogenesis (reviewed in Schmidt-Ott and Kwan 2016). As in germline syncytia, these extra-embryonic syncytia are formed by repeated rounds of nuclear division and incomplete cytokinesis of the yolk sac cytoplasm during blastoderm stages. In some insect species including in Drosophila melanogaster, most of these nuclei then migrate out of the future yolk sac to the embryo surface and contribute to the animal body plan (Campos-Ortega et al. 1997, reviewed in Zissler 1992; 
Davis and Patel 2002). The syncytial yolk nuclei that remain play important roles in embryonic morphogenesis, in part through maintaining integrin-based adhesion with the surrounding embryo (Reed et al. 2004; Benton et al. 2013). In all teleost fishes, the yolk syncytial layer is an extra-embryonic tissue. This tissue is derived from nuclear divisions with incomplete cytokinesis (Lentz and Trinkaus 1967; Kimmel and Law 1985a, b; Chu et al. 2012). The zebrafish yolk syncytial layer, which consists of several hundred nuclei (Carvalho et al. 2009), has numerous roles in early fish development, including nourishing the early embryo (Walzer and Schönenberger 1979a, b) and in signaling events that pattern the embryo (reviewed in Carvalho and Heisenberg 2010; Webb and Miller 2013). Relative to other syncytia, the role of yolk syncytia remains poorly understood. Future studies aimed at specifically disrupting the syncytial nature of the yolk in insect and fish species are needed to understand potential roles of yolk syncytia in embryos.

In many mammals, the extra-embryonic placenta that supports the embryo contains a syncytium. Unlike the examples discussed above in the germline and yolk, cell fusion is the mechanism of syncytium formation in the placenta (reviewed in Gerbaud and Pidoux 2015; Soygur and Sati 2016). In humans, there are three distinctly localized syncytial layers of trophoblast cells in the placenta, each thought to play an endocrine and immune barrier function (reviewed in Turco and Moffett 2019; Roberts et al. 2021). Trophoblast layers may be some of the most extreme examples of syncytia in nature, with up to $6 \times 10^{\wedge} 10$ nuclei estimated in a human syncytial trophoblast (Simpson et al. 1992). In mice, genetic ablation of syncytin molecules, which are endogenous retroviral proteins required for syncytiotrophoblast layer formation, leads to a variety of growth phenotypes, including fetal death (Dupressoir et al. 2009, 2011). Further, altered syncytin expression is reported in human placental pathologies (Chen et al. 2006; Vargas et al. 2011; Soygur et al. 2016). A recent study (Buchrieser et al. 2019) revealed an acute sensitivity of trophoblast syncytium formation to immune signaling through interferons. Upon interferon stimulation in pregnant mice, trophoblast syncytium formation is blocked, leading to halted pregnancy. It is interesting to speculate that the formation of an extraembryonic syncytium provides a developmental checkpoint related to immune sensing. Future work in insect, fish, and mammalian models can further reveal the roles of extraembryonic syncytia, such as whether they allow for more rapid transmission of signals that determine whether embryogenesis should proceed.

\section{Somatic polyploidy}

Following germ cell and embryo stages, extra genomes are seen again as specific somatic lineages differentiate. One general theme of somatic cells with extra genomes is that they can enable the growth of much larger cells (Edgar and Orr-Weaver 2001). In general, cell size growth occurs according to nutrient availability and metabolic capacity (as reviewed in Melaragno et al. 1993; Lloyd 2013; Schoenfelder and Fox 2015). It follows then that adding additional genome copies can support larger cells due to increased metabolism and secretion. This sub-section presents a survey of mononuclear or multinuclear somatic polyploidy, focusing on tissue examples that are conserved in animals.

\section{Cardiomyocytes}

One of the most conserved examples of polyploidy in a somatic tissue is in the cardiac muscle. Cardiomyocytes in the simple heart tube of Drosophila are polyploid (Yu et al. 2013, 2015). In mammals, cardiomyocyte polyploidy appears to have co-evolved with endothermy (Hirose et al. 2019). Fish (including zebrafish), amphibians, and reptiles have little cardiomyocyte polyploidy (Wills et al. 2008; Hirose et al. 2019). Monotremes such as echidna and platypus have moderate levels of cardiomyocyte polyploidy (40-50\% polyploid), while rodents, humans, and other mammals have largely $(90 \%+)$ polyploid cardiomyocytes (Soonpaa et al. 1996; Bergmann et al. 2015; Hirose et al. 2019).

One potential tradeoff to polyploidy in mammals is a loss of regenerative capacity. The diploid zebrafish heart responds to tissue injury using cell division (hyperplasia) to replace dead or missing cells (Poss et al. 2002), and experimentally increasing cardiomyocyte ploidy in this organism decreases regeneration (Gonzalez-Rosa et al. 2018). Instead, polyploid cardiomyocytes in many mammals respond to tissue damage through scarring and cellular and tissue enlargement through further nuclear content 
addition (hypertrophy, Meckert et al. 2005; Patterson et al. 2017; Hirose et al. 2019; Derks and Bergmann 2020; Han et al. 2020). The low rate of cell division in mammals accompanies scarring, and the hypertrophy that results instead of cell division is insufficient to replace lost cardiomyocytes (Senyo et al. 2013).

Cardiomyocytes demonstrate a great range of mononucleate and multinucleate polyploidy throughout the animal kingdom. Within the category of the mammalian heart with $90 \%$ + polyploid adult cardiomyocytes, the number of nuclei per cardiomyocyte varies greatly. Mouse and rat cardiomyocytes are almost entirely binucleate ( 2 nuclei each with 2C DNA content, or $2 \times 2 \mathrm{C}$ ) and are formed by endomitosis with incomplete cytokinesis (Soonpaa et al. 1996; Li et al. 1996, 1997a, b; Engel et al. 2006; Liu et al. 2010, 2019). Adult human cardiomyocytes contain both mononucleated and binucleated cardiomyocytes with typical ploidies of 4-8C, with a range of diploid, tetraploid, and octoploid DNA content (Brodsky et al. 1992; Bergmann et al. 2009, 2015; Mollova et al. 2013). Pig cardiomyocytes typically contain anywhere between 4 and 16 diploid nuclei arranged in a line (Velayutham et al. 2020). Giraffe cardiomyocytes contain 4-8 diploid nuclei also organized linearly, although 4 nuclei are more common (Ostergaard et al. 2013). Most other mammals studied, including sheep, rat, dog, cat, and cow, have predominantly binucleate cardiomyocytes, with each nucleus containing diploid DNA content (Bensley et al. 2016; Velayutham et al. 2019). Future study is needed on non-humate primates and other large mammals to determine the evolution of mononucleate versus multinucleate cardiomyocyte polyploidy. Why mammalian cardiomyocytes have variable nuclear numbers is unknown (see section "Form and Function").

In addition to developmental polyploidization, nuclear content is added in response to heart injury and disease. Human cardiomyocytes reach ploidies up to $32 \mathrm{C}$ in hearts hypertrophied in response to infarction, congenital heart defects, rheumatic heart diseases, and significant hypertension (Brodsky et al. 1994; Herget et al. 1997; Steinhauser and Lee 2011; Senyo et al. 2013). Interestingly, roughly equal populations of mononucleated and binucleated cardiomyocytes are retained after hypertrophy (Brodsky et al. 1994). This suggests that hypertrophic growth largely occurs through ploidy increase in individual nuclei and not the addition of new cells in humans.

\section{Hepatocytes}

Hepatocytes are the major cell type in the vertebrate liver. Like cardiomyocytes, hepatocytes also exhibit species-specific differences in ploidy and nuclear number. Several reviews explore hepatocyte polyploidy in depth (Gentric and Desdouets 2014; Zhang et al. 2019). Hepatocyte polyploidy and multinucleation varies between species. Rat and mouse hepatocytes are $75-90 \%$ polyploid, human hepatocytes are $30-40 \%$ polyploid, and guinea pig and woodchucks have very low levels of hepatocyte polyploidy and binucleation (Kreutz et al. 2017). Mammalian livers also exhibit mixed populations of binucleate and mononucleate polyploid cells, which makes the liver an intriguing system to study their differences. Within the $\sim 30 \%$ polyploid segment of human hepatocytes, binucleate $(2 \times 2 \mathrm{C}$ and $2 \times 4 \mathrm{C})$ and mononucleate $(1 \times 4 \mathrm{C}, 1 \times 8 \mathrm{C})$ polyploid cells are found (Kudryavtsev et al. 1993). The mouse liver contains roughly equal fractions of mononucleate diploid, mononucleate polyploid, binucleate, and binucleate polyploid cells, whereas nuclear number beyond 2 is uncommon (Kreutz et al. 2017). Insects such as Drosophila also have hepatocyte-like cells, known as oenocytes, and these cells also are polyploid (Gutierrez et al. 2006; Cinnamon et al. 2016). The vertebrate liver is highly regenerative, and both diploid hepatocyte division and polyploidy-promoting endocycles or endomitosis are capable of full restoration of liver mass (Davoli et al. 2010; Diril et al. 2012; Miyaoka et al. 2012). In contrast, mice with livers that are incapable of diploid hepatocyte division are prone to a diabetic-like phenotype, inflammation, and fibrosis (Dewhurst et al. 2020; Ow et al. 2020). Further, polyploidy can both promote or suppress liver cancer, depending on the context (Zhang et al. 2018; Lin et al. 2021). Therefore, while multiple hepatocyte ploidies and nuclear numbers can compensate for liver injury, the absence of diploidy can impact hepatocyte metabolism and liver health.

\section{Skeletal muscle}

Skeletal muscle provides an interesting example of a syncytial tissue that uses often high levels of multinucleation and, in some cases, nuclear content increase to grow and adjust to changing demands. Skeletal muscle consists of long, multinucleated muscle fibers 
formed through cell-cell fusion events (reviewed in Deng et al. 2017; Petrany and Millay 2019). In the mouse extensor digitorum longus muscle, there are approximately 220 nuclei per myofiber (Hansson et al. 2020). In some organisms, both cell fusion and ploidy increase within individual nuclei contribute to muscle fiber size growth and function (Windner et al. 2019). One potential hypothesis for why skeletal muscle contains numerous nuclei is the myonuclear domain hypothesis (reviewed in Schwartz 2018), which proposes that each nucleus is responsible for supplying its own territory in the syncytial muscle fiber. The usage of many small nuclei minimizes transport distance of nuclear products to the cytoplasmic domain especially when forming a long cylinder as opposed to a sphere.

Drosophila skeletal muscle employs both multinucleation through cell fusion and nuclear scaling (through regulation of ploidal level) to reach a fixed muscle fiber size (Windner et al. 2019). This suggests that there is coordination between nuclei and sensing of global nuclear content within the muscle fiber. Windner et al. propose a model in which nuclear number, ploidy content, and nucleolus size inform and optimize cell metabolism for the desired muscle fiber size (Windner et al. 2019). A potential advantage of nuclear scaling over cell fusion is the lack of reliance on extrinsic myoblast production. Nuclei already incorporated into the fiber can increase in ploidy in response to signaling. Therefore, the relative contributions of cell fusion and polyploidization may be due to myoblast production potential. The use of both cell fusion and nuclear ploidy increase allows for precise tuning of muscle fiber size and metabolism in Drosophila.

In contrast to fly skeletal muscle, mammalian skeletal muscle appears to only grow through multinucleation. A recent study found that while myonuclear number impacts muscle fiber size within a lower range of nuclear number, the impact of additional myonuclei on fiber size diminishes at a higher range of nuclei. Further, fibers with fewer nuclei can adapt by increasing transcriptional output (Cramer et al. 2020). Skeletal myofibers also experience a limited amount of cellular hypertrophy without DNA replication. However, most adaptive growth after exercise or injury occurs via myonuclear accretion (the addition of nuclei, Goh et al. 2019). The diversity of ploidy organization in tissues such as cardiac and skeletal muscle brings to mind the question-when is mononucleate or multinucleate polyploidy advantageous?

\section{Form and function: when is mononucleate or multinucleate polyploidy advantageous?}

In the preceding sections, we discussed how extra genome copies arise within cells, and what is known about how these extra genomes impact tissue biology. Much remains to be known regarding the function of such whole genome duplication, and integrative studies across diverse models can provide answers (Fox et al. 2020). In this section, we discuss a related question: how does tissue function differ when extra genomes are in one versus many nuclei? In this section we highlight some of the similarities and differences between mononucleate and multinucleate/ syncytial polyploidy and suggest avenues for future study.

Mononucleate and multinucleate polyploid cells are similar

It is not well understood why some tissues can be built or repaired using mononucleate polyploid cells, multinucleate cells, or mixture of the two. There is some evidence that mononucleate and multinucleate cells of the same ploidy do not functionally differ. In the injured Drosophila abdominal epithelium, cell fusion and endocycles collaborate to repair the tissue, yet either mode of genome addition can suffice (Losick et al. 2013, 2016). In the mouse liver, Kreutz et al. and others found no significant difference in cell size and shape between binucleate and mononucleate hepatocytes nor a difference in liver zone location (Martin et al. 2002; Kreutz et al. 2017). However, binucleate and mononucleate polyploid cells do differ in gene expression, with $32 \%$ of differentially expressed genes between these ploidal states (Kreutz et al. 2017). Kreutz et al. speculate that binucleate and mononucleate polyploid cells contribute biological heterogeneity to the liver, although how nuclear number affects hepatic gene expression is unknown (Kreutz et al. 2017).

In the heart, mononucleate and multinucleate murine cardiomyocytes of varying ploidy have similar transcriptional profiles. Single-cell sequencing 
revealed no substantial differences between mononucleate and multinucleate rod-shaped cardiomyocytes isolated from adult mouse ventricle (Yekelchyk et al. 2019). However, transcripts do differ between cardiomyocytes from wild type and hypertrophic hearts (Nomura et al. 2018; Yekelchyk et al. 2019). Megakaryocytes are large, polyploid cells that produce platelets. Mammalian megakaryocytes typically use endomitosis to form polyploid, lobed nuclei (Lordier et al. 2008). The mechanism of ploidy increase does not matter as long as the desired ploidy is achieved. Switching to endocycles for ploidy increase does not impact platelet-forming by megakaryocytes (Trakala et al. 2015). It would be interesting to generate fully multinucleated megakaryocytes to test whether nuclear number similarly does not affect cell function. These findings support the common idea that multinucleate and mononucleate cells of the same ploidy are functionally equivalent.

How mononucleate and multinucleate polyploid cells might differ

We propose here possible reasons that multiple or single nuclei might be beneficial in tissue organization. Some potential differentiating factors could include cell shape, nuclear specialization, and cell division potential. We propose that future studies should consider the existence of a gradient from mononucleated diploid to highly multinucleated cell types (Fig. 2) with distinctive advantages and constraints of each nuclear organization strategy.

Diploid mononucleate cells have unique properties unmatched by polyploid or multinucleated cells such as conventional cell division (Storchova 2014; Schoenfelder and Fox 2015). On the other side of the gradient, highly multinucleated, polyploid cells have unique properties, such as large, complex shapes, that diploid and/or mononucleate cells cannot achieve (Melaragno et al. 1993; Schoenfelder and Fox 2015). In the middle, ploidy and nucleation states may be similar enough to one another to achieve some degree of functional redundance.

Multinucleation may facilitate cell shapes that are not practical or even possible for mononucleated polyploid cells. Cell size is limited by the distance that nuclear products must travel to reach the plasma membrane (Marshall et al. 2012; Schoenfelder and Fox 2015). Human skeletal muscle fibers are giant

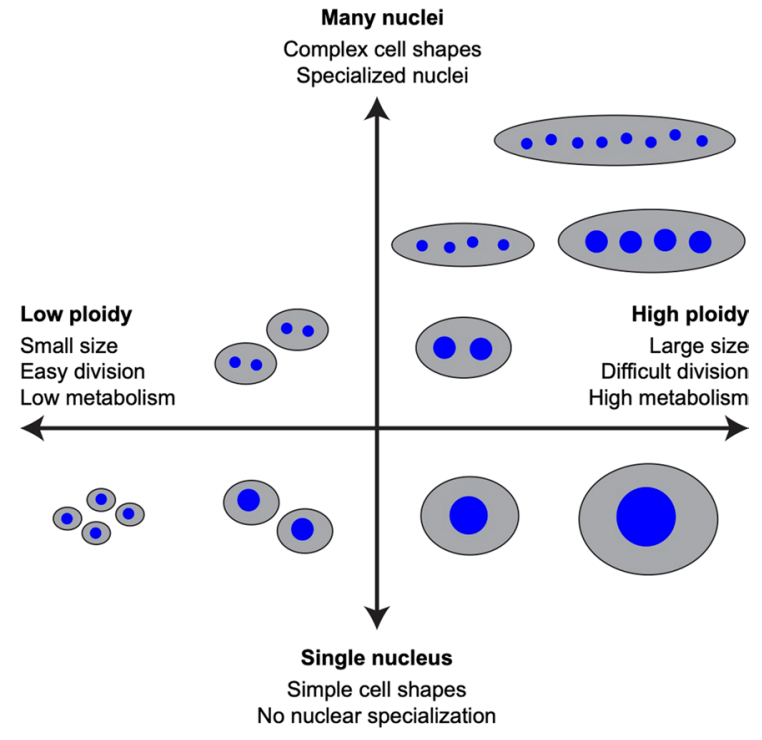

Fig. 2 Ploidy and multinucleation. Axes showing changing cellular properties based on a spectrum from low to high ploidy and nuclear number. "High" and "low" ploidy are kept intentionally vague in this figure, as cell-type-specific biology may impact the properties listed

cells, sometimes containing thousands of nuclei. A giant cell with a singular, 1000C nucleus could not distribute its genetic material and transcriptional activity in the same way that a highly multinucleated cell can. Similarly, the human placental syncytiotrophoblast layer contains hundreds of thousands of nuclei and forms a long, thin, single-celled barrier between the mother and child. The seamless barrier formed by a multinucleated cell does not allow cells or materials to pass. Again, mononucleated polyploidy would be less efficient for a slender barrier. It is less obvious why pig cardiomyocytes grow longitudinally and form elongated cells with 4,8 , or 16 diploid nuclei arranged in a line (Velayutham et al. 2020). The benefit, if any, of building a heart from long cardiomyocytes instead of the shorter, squatter cardiomyocytes seen in mice or humans remains to be seen and should be tested experimentally. The diploid, mononucleated neuron seems to be an exemption to the challenge of long range cellular transport challenges. However, neurons have evolved unique long-distance transport methods (Grafstein and Forman 1980; Steward and Banker 1992). Multinucleation and long-distance transport both facilitate elongated cell shape. 
Another potential advantage of multinucleated cells is the ability to specialize or even remove nuclei. Nuclei in skeletal muscle and syncytial placenta have been shown to have differential transcription within shared cytoplasm (Bursztajn et al. 1989; Fogarty et al. 2011; Petrany et al. 2020). Multinucleate cells formed through cell-cell fusion as opposed to endomitosis, such as skeletal myocyte and syncytiotrophoblast, have an additional advantage as they incorporate newly divided cells. This separation of genetic material allows for transcriptional tuning, such as favoring younger nuclei or nuclei without aneuploidies (imbalanced chromosome number) or DNA damage. In some cases, multinucleated cells can also favor certain nuclei for division. Only the undamaged nucleus divides in binucleate budding yeast with one damaged and one undamaged nucleus (Demeter et al. 2000). Skeletal myocytes gain nuclei after repeated exercise and may lose nuclei upon muscle atrophy although loss of myonuclei through apoptosis was recently disputed (Allen et al. 1999; Schwartz 2018).

Adding extra genomes creates both challenges and opportunities regarding gene dosage regulation (as reviewed in Schoenfelder and Fox 2015). Some degree of specialization is possible in mononucleated polyploid cells through monoallelic gene expression (Huang et al. 2018). Mononucleate and multinucleate are both able to target their gene expression to certain alleles (Bursztajn et al. 1989; Demeter et al. 2000; Fogarty et al. 2011; Huang et al. 2018). However, multinucleate cells have more options to add, remove, and spatially specialize nuclei.

Mononucleated and multinucleated polyploid cells may also differ in their (albeit limited) capacity for cell division. Polyploidy, regardless of nuclear number, is associated with terminal differentiation and a post-mitotic cell state (Lee et al. 2009). However, polyploid cell division has been observed in development and disease. The polyploid mononucleate fruit fly rectal papillar cells undergo programmed, though error-prone cell divisions (Fox et al. 2010; Schoenfelder et al. 2014). Nuclear division also occurs within some syncytial cells such as the synchronous divisions in the Drosophila embryo (reviewed in Foe et al. 1993) and the asynchronous divisions in Ashbya gossypii (Gladfelter et al. 2006). At equivalent ploidy, mononucleate and multinucleate cells face quite different challenges to successfully complete mitosis and cytokinesis. Mononucleate polyploid cells must organize and separate their many additional sister chromatids, which may have altered chromosome structure (reviewed in Stormo and Fox 2017). Multinucleate cells must separate additional nuclei, which can create a challenge for maintaining ploidy (Duncan et al. 2010; Matsumoto et al. 2020). Binucleate cardiomyocytes are capable of forming pseudobipolar spindles in order to divide in vitro, although these divisions are error-prone (Leone and Engel 2019). Both multinuclear and mononuclear polyploid cells face difficulties to complete cell division, although these challenges are specific to the nuclear arrangement. Control of the mitotic spindle assembly checkpoint was found to be a specific vulnerability of polyploid Drosophila and cancer cells, highlighting the heightened challenge of segregating a polyploid genome during mitosis (Stormo and Fox 2016, 2019; Quinton et al. 2021).

Multinucleate polyploid cells may allow slightly larger cell size than equivalently polyploid mononucleate cells. The Drosophila subperineurial glia (SPG) grow and form a blood-brain barrier through both mononucleate and multinucleate polyploidy (Unhavaithaya and Orr-Weaver 2012; Von Stetina et al. 2018). The SPG exhibit regional differences in multinucleation. Seventy percent of the brain lobe SPG are multinucleate and each nucleus is polyploid, while SPG in the peripheral nervous system and ventral nerve cord are solely mononucleate polyploid (Unhavaithaya and Orr-Weaver 2012). The maintenance of a barrier surrounding the proliferating brain requires the presence of both mononucleate and multinucleate polyploid SPG (Von Stetina et al. 2018). Multinucleate SPG are larger than mononucleate SPG of equivalent ploidy but do not differ in cell shape (Von Stetina et al. 2018). However, Von Stetina et al. (Von Stetina et al. 2018) note that size alone may not totally account for the requirement of multinucleate SPG for barrier function. Even when cell shape is comparable, multinucleated cells may be slightly larger than similar mononucleated cells, which could be advantageous for biological barrier maintenance. These findings could be relevant to the recurring role of extra embryonic syncytia as a barrier as discussed in the earlier sub-section "Extraembryonic syncytia." In addition to the placenta, we note that extra nuclei are frequently found to play a barrier protective role in diverse cell types, where they may permit tissue growth/regrowth without compromising 
cell junctions (Unhavaithaya and Orr-Weaver 2012; Losick et al. 2013, 2016; Cohen et al. 2018; Wang et al. 2018).

Finally, cell types that increase in both nuclear ploidy and in nuclear number represent a unique, understudied class of tissues with increased genome content. If multinucleation and mononucleated polyploidy are functionally equivalent, why are both strategies used in the same cell? For example, Drosophila muscle fiber size and metabolism are tuned by both cell fusion and endoreplication as discussed above (Windner et al. 2019). The order of events may also be important. Drosophila muscle fiber fuses to form an elongated cell shape before undergoing endocycles (Windner et al. 2019). We can also imagine the reverse, in which mononucleated cells endocycle to increase in ploidy and then fuse or undergo polyploid mitosis to form a multinucleated cell with polyploid nuclei. For example, mononucleated Drosophila rectal papillar cells undergo endocycles to increase in ploidy and subsequently begin to share cytoplasm. (Peterson et al. 2020). Furthermore, rectal papillar endocycles are required for cytoplasm sharing to occur. We also predict that cells with both nuclear polyploidy and multinucleation would face increased barriers to faithful cell division than cells with only one of the two. Perhaps the combination of the two strategies totally blocks the possibility of division. The intersection of mononucleate and multinucleate polyploidy should be a point of future study.

The mechanisms and roles for polyploidy in development, disease, stress, and injury responses are better understood every year. Mononucleate and multinucleate polyploid cells were once thought to be functionally equivalent. However, we maintain that these two states have unique and intersecting properties that affect tissue architecture and function.

We suggest that additional study aimed at the distinct functions and regulation of mononucleated and multinucleated polyploid cells can reveal benefits of each tissue organization strategy. This should be tested in the in vivo systems described above. Hearts from various species built using different nuclear organization strategies (Table1) should be directly compared given the diversity in cardiomyocyte strategies. In addition, pharmacological and genetic techniques blocking either nuclear division or cytokinesis could be used to convert mononucleate or multinucleate polyploid cells within a certain cell type. For example, cyclin-dependent kinase 1 (Cdk1) ablation can convert endomitoses into endocycles in megakaryocytes, and additional ablation of Cdk2 prevents aberrant re-replication in endocycled megakaryocytes (Trakala et al. 2015). Knock down of fizzy-related $(f z r)$, an anaphase-promoting complex/cyclosome regulator, may convert endocycles into endomitoses or mitoses (Sigrist and Lehner 1997; Schoenfelder et al. 2014; Cohen et al. 2018), depending on whether the cell type has a cytokinetic block such as the partial Rho/Rock defect observed in megakaryocytes (Lordier et al. 2008). In the mouse heart, manipulation of the LaminB2 gene can also impact the degree of mononucleate vs. multinucleate cardiomyocyte ploidy (Han et al. 2020). Between-species comparisons and within-species manipulations will help to determine why tissues use multinucleate and/or mononucleate polyploidy. In addition to the study of naturally occurring cells with extra genomes, future study should include the study of extra genomes in disease, including pathogenic syncytia, such as those produced by SARSCoV-2 (Buchrieser et al. 2020) and the highly prevalent whole genome duplications found in cancer (Zack et al. 2013; Bielski et al. 2018).

\section{Conclusion}

In this review, we have emphasized the wide conservation of cells with greater than diploid genome content in animal tissues. Tissues with extra genomes are frequently required across evolution for gamete formation, embryonic development, and for proper cardiac, liver, and skeletal muscle function. While we have focused on animals, this phenomenon is found throughout nature (e.g., as reviewed in Bomblies 2020). Perhaps due to nomenclature, mononucleate and multinucleate polyploid cells are not often discussed alongside multinucleate syncytia in tissues such as the germline. We argue here that future efforts should compare findings between all examples of extra genomes. Doing so can reveal commonalities in function among diverse tissues with extra genome content, as well as specialized roles for, e.g., large cells with few, highly polyploid nuclei vs. many, lower ploidy nuclei. Much remains to be learned regarding the need for cellular collectives in tissue biology. 
Abbreviations $S P G$; Subperineurial glia: Fzr; Fizzyrelated: $C d k$; Cyclin-dependent kinase

Acknowledgements We thank those whose work contributed to the knowledge base discussed in this review but whom we were unable to cite due to space limitations. We thank Rebeccah Stewart and Yarui Diao for comments on the manuscript. This project was supported by NHLBI grant HL140811 to NP and NIGMS grant GM118447 to DF.

\section{References}

Allen DL, Roy RR, Edgerton VR (1999) Myonuclear domains in muscle adaptation and disease. Muscle Nerve 22:1350-1360. https://doi.org/10.1002/(sici)10974598(199910)22:10[1350::aid-mus3]3.0.co;2-8

Amini R, Goupil E, Labella S et al (2014) C. Elegans Anillin proteins regulate intercellular bridge stability and germline syncytial organization. J Cell Biol 206:129-143. https://doi.org/10.1083/jcb.201310117

Barlow PW, Sherman MI (1972) The biochemistry of differentiation of mouse trophoblast: studies on polyploidy. $\mathbf{J}$ Embryol Exp Morphol 27:447-465

Bensley JG, De Matteo R, Harding R, Black MJ (2016) Threedimensional direct measurement of cardiomyocyte volume, nuclearity, and ploidy in thick histological sections. Sci Rep 6:23756. https://doi.org/10.1038/srep23756

Benton MA, Akam M, Pavlopoulos A (2013) Cell and tissue dynamics during Tribolium embryogenesis revealed by versatile fluorescence labeling approaches. Development 140:3210-3220. https://doi.org/10.1242/dev.096271

Bergmann O, Bhardwaj RD, Bernard S et al (2009) Evidence for cardiomyocyte renewal in humans. Science 324:98102. https://doi.org/10.1126/science. 1164680

Bergmann O, Zdunek S, Felker A et al (2015) Dynamics of cell generation and turnover in the human heart. Cell 161:1566-1575

Bielski CM, Zehir A, Penson AV et al (2018) Genome doubling shapes the evolution and prognosis of advanced cancers. Nat Genet 50:1189-1195. https://doi.org/10. 1038/s41588-018-0165-1

Bolívar J, Huynh JR, López-Schier H et al (2001) Centrosome migration into the Drosophila oocyte is independent of BicD and egl, and of the organisation of the microtubule cytoskeleton. Development 128:1889-1897

Bomblies K (2020) When everything changes at once: finding a new normal after genome duplication. Proc R Soc B Biol Sci 287:20202154. https://doi.org/10.1098/rspb. 2020.2154

Braun RE, Behringer RR, Peschon JJ et al (1989) Genetically haploid spermatids are phenotypically diploid. Nature 337:373-376. https://doi.org/10.1038/337373a0

Brodsky VY, Chernyaev AL, Vasilyeva IA (1992) Variability of the cardiomyocyte ploidy in normal human hearts. Virchows Arch B Cell Pathol Incl Mol Pathol 61:289294. https://doi.org/10.1007/BF02890430

Brodsky VY, Sarkisov DS, Arefyeva AM et al (1994) Polyploidy in cardiac myocytes of normal and hypertrophic human hearts; range of values. Virchows Arch 424:429-435. https://doi.org/10.1007/BF00190566

Brown AS, Hong Y, De Belder A et al (1997) Megakaryocyte ploidy and platelet changes in human diabetes and atherosclerosis. Arterioscler Thromb Vasc Biol 17:802-807. https://doi.org/10.1161/01.ATV.17.4.802

Buchrieser J, Degrelle SA, Couderc T et al (2019) IFITM proteins inhibit placental syncytiotrophoblast formation and promote fetal demise. Science 365:176-180. https://doi.org/10.1126/science.aaw7733

Buchrieser J, Dufloo J, Hubert M et al (2020) Syncytia formation by SARS-CoV-2-infected cells. EMBO J 39:e106267

Bursztajn S, Berman SA, Gilbert W (1989) Differential expression of acetylcholine receptor mRNA in nuclei of cultured muscle cells. Proc Natl Acad Sci U S A 86:29282932. https://doi.org/10.1073/pnas.86.8.2928

Caldwell KA, Handel MA (1991) Protamine transcript sharing among postmeiotic spermatids. Proc Natl Acad Sci U S A 88:2407-2411. https://doi.org/10.1073/pnas.88.6.2407

Campos-Ortega JA, Hartenstein V, Campos-Ortega JA, Hartenstein V (1997) The Embryonic Development of Drosophila melanogaster. Springer, Berlin Heidelberg

Carvalho L, Heisenberg CP (2010) The yolk syncytial layer in early zebrafish development. Trends Cell Biol 20:586-592

Carvalho L, Stühmer J, Bois JS et al (2009) Control of convergent yolk syncytial layer nuclear movement in zebrafish. Development 136:1305-1315. https://doi.org/10.1242/ dev.026922

Chen C-P, Wang K-G, Chen C-Y et al (2006) Altered placental syncytin and its receptor ASCT2 expression in placental development and pre-eclampsia. BJOG an Int J Obstet Gynaecol 113:152-158. https://doi.org/10.1111/j.14710528.2005.00843.x

Chu LT, Fong SH, Kondrychyn I et al (2012) Yolk syncytial layer formation is a failure of cytokinesis mediated by Rock1 function in the early zebrafish embryo. Biol Open 1:747-753. https://doi.org/10.1242/bio.20121636

Cinnamon E, Makki R, Sawala A et al (2016) Drosophila Spidey/Kar Regulates Oenocyte Growth via PI3-Kinase Signaling. PLOS Genet 12:e1006154. https://doi.org/10. 1371/journal.pgen.1006154

Cohen E, Allen SR, Sawyer JK, Fox DT (2018) Fizzy-related dictates a cell cycle switch during organ repair and tissue growth responses in the drosophila hindgut. Elife 7:e38327. https://doi.org/10.7554/eLife.38327

Cox RT, Spradling AC (2003) A Balbiani body and the fusome mediate mitochondrial inheritance during Drosophila oogenesis. Development 130:1579-1590

Cramer AAW, Prasad V, Eftestol E et al (2020) Nuclear numbers in syncytial muscle fibers promote size but limit the development of larger myonuclear domains. Nat Commun 11:6287. https://doi.org/10.1038/ s41467-020-20058-7

Davis GK, Patel NH (2002) Short, long, and beyond: Molecular and embryological approaches to insect segmentation. Annu Rev Entomol 47:669-699

Davoli T, Denchi EL, de Lange T (2010) Persistent telomere damage induces bypass of mitosis and tetraploidy. Cell 141:81-93 
de Cuevas M, Lilly M, Spradling A (1997) Germline cyst formation in drosophila. Annu Rev Genet 31:405-428. https://doi.org/10.1146/annurev.genet.31.1.405

Demeter J, Lee SE, Haber JE, Stearns T (2000) The DNA damage checkpoint signal in budding yeast is nuclear limited. Mol Cell 6:487-492. https://doi.org/10.1016/s10972765(00)00047-2

Deng S, Azevedo M, Baylies M (2017) Acting on identity: myoblast fusion and the formation of the syncytial muscle fiber. Semin Cell Dev Biol 72:45-55. https://doi.org/ 10.1016/j.semcdb.2017.10.033

Derks W, Bergmann O (2020) Polyploidy in cardiomyocytes: roadblock to heart regeneration? Circ Res 126:552-565. https://doi.org/10.1161/CIRCRESAHA.119.315408

Dewhurst MR, Ow JR, Zafer G, et al (2020) Loss of hepatocyte cell division leads to liver inflammation and fibrosis. PLoS Genet 16: https://doi.org/10.1371/journal.pgen. 1009084

Diril MK, Ratnacaram CK, Padmakumar VC et al (2012) Cyclin-dependent kinase 1 (Cdk1) is essential for cell division and suppression of DNA re-replication but not for liver regeneration. Proc Natl Acad Sci U S A 109:38263831. https://doi.org/10.1073/pnas.1115201109

Duncan AW, Taylor MH, Hickey RD et al (2010) The ploidy conveyor of mature hepatocytes as a source of genetic variation. Nature 467:707-710

Dupressoir A, Vernochet C, Bawa O et al (2009) Syncytin-A knockout mice demonstrate the critical role in placentation of a fusogenic, endogenous retrovirus-derived, envelope gene. Proc Natl Acad Sci U S A 106:12127-12132. https://doi.org/10.1073/pnas.0902925106

Dupressoir A, Vernochet C, Harper F et al (2011) A pair of co-opted retroviral envelope syncytin genes is required for formation of the two-layered murine placental syncytiotrophoblast. Proc Natl Acad Sci U S A 108:E1164E1173. https://doi.org/10.1073/pnas.1112304108

Edgar BA, Orr-Weaver TL (2001) Endoreplication cell cycles: more for less. Cell 105:297-306

Engel FB, Schebesta M, Keating MT (2006) Anillin localization defect in cardiomyocyte binucleation. J Mol Cell Cardiol 41:601-612. https://doi.org/10.1016/j.yjmcc. 2006.06.012

Fawcett DW, Ito S, Slautterback D (1959) The occurrence of intercellular bridges in groups of cells exhibiting. J Biophys Biochem Cytol 5:453-460. https://doi.org/10.1083/ jcb.5.3.453

Foe VE, Odell GM, Edgar BA (1993) Mitosis and morphogenesis in the Drosophila embryo. In: Bate M, MartinezArias A (eds) The Development of Drosophila melanogaster. Cold Spring Harbor Press, pp 149-300

Fogarty NM, Mayhew TM, Ferguson-Smith AC, Burton GJ (2011) A quantitative analysis of transcriptionally active syncytiotrophoblast nuclei across human gestation. J Anat 219:601-610. https://doi.org/10.1111/j.1469-7580. 2011.01417.x

Foley K, Cooley L (1998) Apoptosis in late stage Drosophila nurse cells does not require genes within the H99 deficiency. Development 125:1075-1082

Fox DT, Duronio RJ (2013) Endoreplication and polyploidy: new insights into development and disease. Development 140:3-12. https://doi.org/10.1242/dev.080531
Fox DT, Gall JG, Spradling AC (2010) Error-prone polyploid mitosis during normal Drosophila development. Genes Dev 24:2294-2302. https://doi.org/10.1101/gad.1952710

Fox DT, Soltis DE, Soltis PS et al (2020) Polyploidy: a biological force from cells to ecosystems. Trends Cell Biol 30:688-694. https://doi.org/10.1016/j.tcb.2020.06.006

Gentric G, Desdouets C (2014) Polyploidization in liver tissue. Am J Pathol 184:322-331

Gerbaud P, Pidoux G (2015) Review: an overview of molecular events occurring in human trophoblast fusion. Placenta $36: \mathrm{S} 35-\mathrm{S} 42$

Gladfelter AS, Hungerbuehler AK, Philippsen P (2006) Asynchronous nuclear division cycles in multinucleated cells. J Cell Biol 172:347-362. https://doi.org/10.1083/jcb. 200507003

Goh Q, Song T, Petrany MJ, et al (2019) Myonuclear accretion is a determinant of exercise-induced remodeling in skeletal muscle. Elife 8: https://doi.org/10.7554/eLife.44876

Gonzalez-Rosa JM, Sharpe M, Field D et al (2018) Myocardial Polyploidization Creates a Barrier to Heart Regeneration in Zebrafish. Dev Cell 44(433-446):e7. https://doi.org/ 10.1016/j.devcel.2018.01.021

Grafstein B, Forman DS (1980) Intracellular transport in neurons. Physiol Rev 60:1167-1283. https://doi.org/10.1152/ physrev.1980.60.4.1167

Greenbaum MP, Iwamori T, Buchold GM, Matzuk MM (2011) Germ cell intercellular bridges. Cold Spring Harb Perspect Biol 3:1-18. https://doi.org/10.1101/cshperspect. a005850

Greenspan LJ, De Cuevas M, Matunis E (2015) Genetics of Gonadal Stem Cell Renewal. Annu Rev Cell Dev Biol 31:291-315. https://doi.org/10.1146/annurev-cellbio-100913-013344

Gutierrez E, Wiggins D, Fielding B, Gould AP (2006) Specialized hepatocyte-like cells regulate Drosophila lipid metabolism. Nature 445:275-280. https://doi.org/10. 1038/nature 05382

Gutzeit HO (1986) The role of microfilaments in cytoplasmic streaming in Drosophila follicles. J Cell Sci 80:159-169

Hammond MP, Laird CD (1985) Control of DNA replication and spatial distribution of defined DNA sequences in salivary gland cells of Drosophila melanogaster. Chromosoma 91:279-286. https://doi.org/10.1007/BF00328223

Han L, Choudhury S, Mich-Basso JD et al (2020) Lamin B2 levels regulate polyploidization of cardiomyocyte nuclei and myocardial regeneration. Dev Cell 53:42-59.e11. https://doi.org/10.1016/j.devcel.2020.01.030

Hansson KA, Eftestøl E, Bruusgaard JC et al (2020) Myonuclear content regulates cell size with similar scaling properties in mice and humans. Nat Commun 11:1-14. https://doi.org/10.1038/s41467-020-20057-8

Herget GW, Neuburger M, Plagwitz R, Adler CP (1997) DNA content, ploidy level and number of nuclei in the human heart after myocardial infarction. Cardiovasc Res 36:45-51

Hernandez JM, Podbilewicz B (2017) The Hallmarks of CellCell Fusion. Development 144:4481-4495. https://doi. org/10.1242/dev. 155523

Herrtwich L, Nanda I, Evangelou K et al (2016) DNA damage signaling instructs polyploid macrophage fate in granulomas. Cell 167:1264-1280.e18. https://doi.org/ 10.1016/j.cell.2016.09.054 
Hesse M, Raulf A, Pilz G-A et al (2012) Direct visualization of cell division using high-resolution imaging of M-phase of the cell cycle. Nat Commun 3:1076

Hime GR, Brill JA, Fuller MT (1996) Assembly of ring canals in the male germ line from structural components of the contractile ring. J Cell Sci 109:2779-2788

Hirose K, Payumo AY, Cutie S et al (2019) Evidence for hormonal control of heart regenerative capacity during endothermy acquisition. Science 364:184-188. https:// doi.org/10.1126/science.aar2038

Huang WC, Bennett K, Gregg C (2018) Epigenetic and cellular diversity in the brain through allele-specific effects. Trends Neurosci 41:925-937. https://doi.org/10.1016/j. tins.2018.07.005

Kaufman RS, Price KL, Mannix KM et al (2020) Drosophila sperm development and intercellular cytoplasm sharing through ring canals do not require an intact fusome. Development 147:dev190140. https://doi.org/10.1242/ dev. 190140

Kimmel CB, Law RD (1985a) Cell lineage of zebrafish blastomeres. I. Cleavage pattern and cytoplasmic bridges between cells. Dev Biol 108:78-85. https://doi.org/10. 1016/0012-1606(85)90010-7

Kimmel CB, Law RD (1985b) Cell lineage of zebrafish blastomeres. II. Formation of the yolk syncytial layer. Dev Biol 108:86-93. https://doi.org/10.1016/0012-1606(85) 90011-9

Kloc M, Bilinski S, Dougherty MT et al (2004) Formation, architecture and polarity of female germline cyst in Xenopus. Dev Biol 266:43-61. https://doi.org/10. 1016/j.ydbio.2003.10.002

Kosaka K, Kawakami K, Sakamoto H, Inoue K (2007) Spatiotemporal localization of germ plasm RNAs during zebrafish oogenesis. Mech Dev 124:279-289. https:// doi.org/10.1016/j.mod.2007.01.003

Kreutz C, MacNelly S, Follo M, et al (2017) Hepatocyte ploidy is a diversity factor for liver homeostasis. Front Physiol 8: https://doi.org/10.3389/fphys.2017.00862

Kudryavtsev BN, Kudryavtseva MV, Sakuta GA, Stein GI (1993) Human hepatocyte polyploidization kinetics in the course of life cycle. Virchows Arch B Cell Pathol Incl Mol Pathol 64:387-393. https://doi.org/10.1007/ BF02915139

Lang L, Schnittger A (2020) Endoreplication - a means to an end in cell growth and stress response. Curr Opin Plant Biol 54:85-92. https://doi.org/10.1016/j.pbi.2020.02. 006

Lazzeri E, Angelotti ML, Conte C, Anders HJ RP (2019) Surviving acute organ failure: cell polyploidization and progenitor proliferation. Trends Mol Med Epub ahead of print:30041-3. https://doi.org/10.1016/j.molmed.2019. 02.006

Lee DM, Chen EH (2019) Drosophila myoblast fusion: invasion and resistance for the ultimate union. Annu Rev Genet 53:67-91. https://doi.org/10.1146/annur ev-genet-120116-024603

Lee HO, Davidson JM, Duronio RJ (2009) Endoreplication: polyploidy with purpose. Genes Dev 23:2461-2477

Lei L, Spradling AC (2013) Mouse primordial germ cells produce cysts that partially fragment prior to meiosis. Dev 140:2075-2081. https://doi.org/10.1242/dev.093864
Lei L, Spradling AC (2016) Mouse oocytes differentiate through organelle enrichment from sister cyst germ cells. Science 352:95-99. https://doi.org/10.1126/science. aad2156

Lentz TL, Trinkaus JP (1967) A fine structural study of cytodifferentiation during cleavage, blastula, and gastrula stages of Fundulus heteroclitus. J Cell Biol 32:121-138. https://doi.org/10.1083/jcb.32.1.121

Leone M, Engel FB (2019) Pseudo-bipolar spindle formation and cell division in postnatal binucleated cardiomyocytes. J Mol Cell Cardiol 134:69-73. https://doi.org/10. 1016/j.yjmcc.2019.07.005

Li F, McNelis MR, Lustig K, Gerdes AM (1997a) Hyperplasia and hypertrophy of chicken cardiac myocytes during gposthatching development. Am J Physiol - Regul Integr Comp Physiol 273: https://doi.org/10.1152/ajpregu.1997. 273.2.r518

Li F, Wang X, Bunger PC, Gerdes AM (1997b) Formation of binucleated cardiac myocytes in rat heart: I. Role of actin-myosin contractile ring. J Mol Cell Cardiol 29:1541-1551. https://doi.org/10.1006/jmcc.1997.0381

Li F, Wang X, Capasso JM, Gerdes AM (1996) Rapid transition of cardiac myocytes from hyperplasia to hypertrophy during postnatal development. J Mol Cell Cardiol 28:1737-1746

Lin H, Huang YS, Fustin JM et al (2021) Hyperpolyploidization of hepatocyte initiates preneoplastic lesion formation in the liver. Nat Commun 12:1-18. https://doi.org/ 10.1038/s41467-020-20572-8

Liu H, Zhang CH, Ammanamanchi N, et al (2019) Control of cytokinesis by $\beta$-adrenergic receptors indicates an approach for regulating cardiomyocyte endowment. Sci Transl Med 11: https://doi.org/10.1126/scitranslmed.aaw6419

Liu Z, Yue S, Chen X et al (2010) Regulation of cardiomyocyte polyploidy and multinucleation by CyclinG1. Circ Res 106:1498-1506

Lloyd AC (2013) The Regulation of Cell Size. Cell 154:1194-1205

Lordier L, Jalil A, Aurade F et al (2008) Megakaryocyte endomitosis is a failure of late cytokinesis related to defects in the contractile ring and Rho/Rock signaling. Blood 112:3164-3174. https://doi.org/10.1182/ blood-2008-03-144956

Losick VP, Fox DT, Spradling AC (2013) Polyploidization and cell fusion contribute to wound healing in the adult Drosophila epithelium. Curr Biol 23:2224-2232. https://doi. org/10.1016/j.cub.2013.09.029

Losick VP, Jun AS, Spradling AC (2016) Wound-induced polyploidization: Regulation by hippo and JNK signaling and conservation in Mammals. PLoS One 11:e0151251-. https://doi.org/10.1371/journal.pone.0151251

Lu K, Jensen L, Lei L, Yamashita YM (2017) Stay connected: a germ cell strategy. Trends Genet 33:971-978

Lucchetta EM, Ohlstein B (2017) Amitosis of polyploid cells regenerates functional stem cells in the Drosophila intestine. Cell Stem Cell 20:609-620.e6. https://doi.org/10. 1016/j.stem.2017.02.012

MacAuley A, Cross JC, Werb Z (1998) Reprogramming the cell cycle for endoreduplication in rodent trophoblast cells. Mol Biol Cell 9:795-807. https://doi.org/10.1091/ mbc.9.4.795 
Maddox AS, Habermann B, Desai A, Oegema K (2005) Distinct roles for two C. elegans anillins in the gonad and early embryo. Development 132:2837-2848. https://doi. org/10.1242/dev.01828

Marlow FL, Mullins MC (2008) Bucky ball functions in Balbiani body assembly and animal-vegetal polarity in the oocyte and follicle cell layer in zebrafish. Dev Biol 321:40-50. https://doi.org/10.1016/j.ydbio.2008.05.557

Marshall WF, Young KD, Swaffer M et al (2012) What determines cell size? BMC Biol 10:101. https://doi.org/10. 1186/1741-7007-10-101

Martin NC, McCullough CT, Bush PG et al (2002) Functional analysis of mouse hepatocytes differing in DNA content: Volume, receptor expression, and effect of IFN $\gamma$. J Cell Physiol 191:138-144. https://doi.org/10.1002/jcp.10057

Matsumoto T, Wakefield L, Peters A, et al (2021) Proliferative polyploid cells give rise to tumors via ploidy reduction. Nat Commun 12:. https://doi.org/10.1038/ s41467-021-20916-y

Matsumoto T, Wakefield L, Tarlow BD, Grompe M (2020) In vivo lineage tracing of polyploid hepatocytes reveals extensive proliferation during liver regeneration. Cell Stem Cell 26:34-47.e3. https://doi.org/10.1016/j.stem. 2019.11.014

McCall K, Steller H (1998) Requirement for DCP-1 caspase during Drosophila oogenesis. Science 279:230-234. https://doi.org/10.1126/science.279.5348.230

Meckert PC, Rivello H a n G, Vigliano C, et al (2005) Endomitosis and polyploidization of myocardial cells in the periphery of human acute myocardial infarction. Cardiovasc Res 67:116-123

Melaragno JE, Mehrotra B, Coleman AW (1993) Relationship between endopolyploidy and cell size in epidermal tissue of arabidopsis. Plant Cell 5:1661-1668

Miyaoka Y, Ebato K, Kato H et al (2012) Hypertrophy and unconventional cell division of hepatocytes underlie liver regeneration. Curr Biol 22:1166-1175

Mollova M, Bersell K, Walsh S et al (2013) Cardiomyocyte proliferation contributes to heart growth in young humans. Proc Natl Acad Sci U S A 110:1446-1451. https://doi.org/10.1073/pnas.1214608110

Nomura S, Satoh M, Fujita T et al (2018) Cardiomyocyte gene programs encoding morphological and functional signatures in cardiac hypertrophy and failure. Nat Commun 9:4435. https://doi.org/10.1038/s41467-018-06639-7

Odell TT, Murphy JR, Jackson CW (1976) Stimulation of megakaryocytopoiesis by acute thrombocytopenia in rats. Blood 48:765-775. https://doi.org/10.1182/blood.v48.5. 765.765

Ostergaard KH, Baandrup UT, Wang T et al (2013) Left ventricular morphology of the giraffe heart examined by stereological methods. Anat Rec 296:611-621. https://doi. org/10.1002/ar.22672

Øvrebø JI, Edgar BA (2018) Polyploidy in tissue homeostasis and regeneration. Dev 145: https://doi.org/10.1242/dev. 156034

Ow JR, Cadez MJ, Zafer G et al (2020) Remodeling of wholebody lipid metabolism and a diabetic-like phenotype caused by loss of CDK1 and hepatocyte division. Elife 9:1-34. https://doi.org/10.7554/eLife.63835
Patterson M, Barske L, Van Handel B et al (2017) Frequency of mononuclear diploid cardiomyocytes underlies natural variation in heart regeneration. Nat Genet 49:1346-1353. https://doi.org/10.1038/ng.3929

Pepling ME, Spradling AC (2001) Mouse ovarian germ cell cysts undergo programmed breakdown to form primordial follicles. Dev Biol 234:339-351. https://doi.org/10. 1006/dbio.2001.0269

Peterson NG, Stormo BM, Schoenfelder KP, et al (2020) Cytoplasmic sharing through apical membrane remodeling. Elife 9:. https://doi.org/10.7554/eLife.58107

Petrany MJ, Millay DP (2019) Cell fusion: merging membranes and making muscle. Trends Cell Biol 29:964973. https://doi.org/10.1016/j.tcb.2019.09.002

Petrany MJ, Swoboda CO, Sun C et al (2020) Single-nucleus RNA-seq identifies transcriptional heterogeneity in multinucleated skeletal myofibers. Nat Commun 11:1-12. https://doi.org/10.1038/s41467-020-20063-w

Piper K, Boyde A, Jones SJ (1992) The relationship between the number of nuclei of an osteoclast and its resorptive capability in vitro. Anat Embryol 186:291-299. https:// doi.org/10.1007/BF00185977

Poss KD, Wilson LG, Keating MT (2002) Heart regeneration in zebrafish. Sci (new York, NY) 298:2188-2190

Priti A, Ong HT, Toyama Y et al (2018) Syncytial germline architecture is actively maintained by contraction of an internal actomyosin corset. Nat Commun 9:1-15. https:// doi.org/10.1038/s41467-018-07149-2

Quinton RJ, DiDomizio A, Vittoria MA et al (2021) Wholegenome doubling confers unique genetic vulnerabilities on tumour cells. Nature 590:492-497. https://doi.org/10. 1038/s41586-020-03133-3

Reed BH, Wilk R, Schöck F, Lipshitz HD (2004) Integrindependent apposition of Drosophila extraembryonic membranes promotes morphogenesis and prevents anoikis. Curr Biol 14:372-380. https://doi.org/10.1016/j. cub.2004.02.029

Roberts RM, Ezashi T, Schulz LC et al (2021) Syncytins expressed in human placental trophoblast. Placenta. https://doi.org/10.1016/j.placenta.2021.01.006

Ruby JR, Dyer RF, Skalko RG (1969) The occurrence of intercellular bridges during oogenesis in the mouse. J Morphol 127:307-339. https://doi.org/10.1002/jmor.10512 70304

Schmidt-Ott U, Kwan CW (2016) Morphogenetic functions of extraembryonic membranes in insects. Curr Opin Insect Sci 13:86-92

Schoenfelder KP, Fox DT (2015) The expanding implications of polyploidy. J Cell Biol 209:485-491. https://doi.org/ 10.1083/jcb.201502016

Schoenfelder KP, Montague RA, Paramore SV et al (2014) Indispensable pre-mitotic endocycles promote aneuploidy in the Drosophila rectum. Development 141:3551-3560. https://doi.org/10.1242/dev.109850

Schwartz LM (2018) Skeletal muscles do not undergo apoptosis during either atrophy or programmed cell death-revisiting the myonuclear domain hypothesis. Front Physiol 9:1887. https://doi.org/10.3389/fphys.2018.01887

Senyo SE, Steinhauser ML, Pizzimenti CL et al (2013) Mammalian heart renewal by pre-existing cardiomyocytes. Nature 493:433-436 
Shu Z, Row S, Deng WM (2018) Endoreplication: The Good, the Bad, and the Ugly. Trends Cell Biol 28:465-474. https://doi.org/10.1016/j.tcb.2018.02.006

Sigrist SJ, Lehner CF (1997) Drosophila fizzy-related downregulates mitotic cyclins and is required for cell proliferation arrest and entry into endocycles. Cell 90:671-681

Simpson RA, Mayhew TM, Barnes PR (1992) From 13 weeks to term, the trophoblast of human placenta grows by the continuous recruitment of new proliferative units: A study of nuclear number using the disector. Placenta 13:501-512. https://doi.org/10.1016/0143-4004(92) 90055-X

Soonpaa MH, Kim KK, Pajak L et al (1996) Cardiomyocyte DNA synthesis and binucleation during murine development. Am J Physiol 271:H2183-H2189. https://doi.org/ 10.1152/ajpheart.1996.271.5.H2183

Soygur B, Sati L (2016) The role of syncytins in human reproduction and reproductive organ cancers. Reproduction 152:R167-R178

Soygur B, Sati L, Demir R (2016) Altered expression of human endogenous retroviruses syncytin-1, syncytin-2 and their receptors in human normal and gestational diabetic placenta. Histol Histopathol 31:1037-1047. https://doi.org/ 10.14670/HH-11-735

Steinhauser ML, Lee RT (2011) Regeneration of the heart. EMBO Mol Med 3:701-712

Steward O, Banker GA (1992) Getting the message from the gene to the synapse: sorting and intracellular transport of RNA in neurons. Trends Neurosci 15:180-186. https:// doi.org/10.1016/0166-2236(92)90170-d

Storchova Z (2014) Ploidy changes and genome stability in yeast. Yeast 31:421-430

Stormo BM, Fox DT (2019) Interphase cohesin regulation ensures mitotic fidelity after genome reduplication. Mol Biol Cell 30: https://doi.org/10.1091/mbc.E17-10-0582

Stormo BM, Fox DT (2017) Polyteny: still a giant player in chromosome research. Chromosom Res 25:201-214. https://doi.org/10.1007/s10577-017-9562-z

Stormo BM, Fox DT (2016) Distinct responses to reduplicated chromosomes require distinct $\mathrm{Mad} 2$ responses. Elife 5:2275. https://doi.org/10.7554/eLife.15204

Trakala M, Rodríguez-Acebes S, Maroto M et al (2015) Functional Reprogramming of Polyploidization in Megakaryocytes. Dev Cell 32:155-167. https://doi.org/10.1016/j. devcel.2014.12.015

Turco MY, Moffett A (2019) Development of the human placenta. Dev. 146

Unhavaithaya Y, Orr-Weaver TL (2012) Polyploidization of glia in neural development links tissue growth to bloodbrain barrier integrity. Genes Dev 26:31-36

Vargas A, Toufaily C, Lebellego F et al (2011) Reduced expression of both syncytin 1 and syncytin 2 correlates with severity of preeclampsia. Reprod Sci 18:1085-1091. https://doi.org/10.1177/1933719111404608

Velayutham N, Agnew EJ, Yutzey KE (2019) Postnatal cardiac development and regenerative potential in large mammals. Pediatr Cardiol 40:1345-1358. https://doi. org/10.1007/s00246-019-02163-7

Velayutham N, Alfieri CM, Agnew EJ et al (2020) Cardiomyocyte cell cycling, maturation, and growth by multinucleation in postnatal swine. J Mol Cell Cardiol
146:95-108. https://doi.org/10.1016/j.yjmcc.2020.07. 004

Ventelä S, Toppari J, Parvinen M (2003) Intercellular organelle traffic through cytoplasmic bridges in early spermatids of the rat: Mechanisms of haploid gene product sharing. Mol Biol Cell 14:2768-2780. https://doi.org/ 10.1091/mbc.E02-10-0647

Von Stetina JR, Frawley LE, Unhavaithaya Y, Orr-Weaver TL (2018) Variant cell cycles regulated by Notch signaling control cell size and ensure a functional blood-brain barrier. Development 145:dev157115

Walzer C, Schönenberger N (1979a) Ultrastructure and cytochemistry of the yolk syncytial layer in the alevin of trout (Salmo fario trutta L. and Salmo gairdneri R.) after hatching - II. The Cytoplasmic Zone Cell Tissue Res 196:75-93. https://doi.org/10.1007/BF00236349

Walzer C, Schönenberger N (1979b) Ultrastructure and cytochemistry study of the yolk syncytial layer in the alevin of trout (Salmo fario trutta L.) after hatching - I. The Vitellolysis Zone Cell Tissue Res 196:59-73. https:// doi.org/10.1007/BF00236348

Wang J, Batourina E, Schneider K et al (2018) Polyploid superficial cells that maintain the urothelial barrier are produced via incomplete cytokinesis and endoreplication. Cell Rep 25:464-477.e4. https://doi.org/10.1016/j. celrep.2018.09.042

Webb SE, Miller AL (2013) Calcium signaling in extraembryonic domains during early teleost development. In: International Review of Cell and Molecular Biology. Elsevier Inc., pp 369-418

Wills AA, Holdway JE, Major RJ, Poss KD (2008) Regulated addition of new myocardial and epicardial cells fosters homeostatic cardiac growth and maintenance in adult zebrafish. Development 135:183-192. https://doi.org/ 10.1242/dev.010363

Windner SE, Manhart A, Brown A et al (2019) Nuclear Scaling Is Coordinated among Individual Nuclei in Multinucleated Muscle Fibers. Dev Cell 49(48-62):e3. https://doi.org/10.1016/j.devcel.2019.02.020

Yamashita YM (2018) Subcellular specialization and organelle behavior in germ cells. Genetics 208:19-51

Yekelchyk M, Guenther S, Preussner J, Braun T (2019) Mono- and multi-nucleated ventricular cardiomyocytes constitute a transcriptionally homogenous cell population. Basic Res Cardiol 114:36. https://doi.org/10.1007/ s00395-019-0744-z

Yoshida S (2016) From cyst to tubule: Innovations in vertebrate spermatogenesis. Wiley Interdiscip Rev Dev Biol 5:119-131. https://doi.org/10.1002/wdev.204

Yu L, Daniels J, Glaser AE, Wolf MJ (2013) Raf-mediated cardiac hypertrophy in adult Drosophila. Dis Model Mech 6:964-976

Yu L, Daniels JP, Wu H, Wolf MJ (2015) Cardiac hypertrophy induced by active Raf depends on Yorkie-mediated transcription. Sci Signal 8:ra13. https://doi.org/10. 1126/scisignal.2005719

Zack TI, Schumacher SE, Carter SL et al (2013) Pan-cancer patterns of somatic copy number alteration. Nat Genet 45:1134-1140. https://doi.org/10.1038/ng.2760

Zamboni L, Gonndos B (1968) Intercellular bridges and synchronization of germ cell differentiation during oogenesis 
in the rabbit. J Cell Biol 36:276-282. https://doi.org/10. 1083/jcb.36.1.276

Zhang S, Lin YH, Tarlow B, Zhu H (2019) The origins and functions of hepatic polyploidy. Cell Cycle 18:1302-1315

Zhang S, Zhou K, Luo X et al (2018) The polyploid state plays a tumor-suppressive role in the liver. Dev Cell 44:447459.e5. https://doi.org/10.1016/j.devcel.2018.01.010
Zissler D (1992) From egg to pole cells: Ultrastructural aspects of early cleavage and germ cell determination in insects. Microsc Res Tech 22:49-74. https://doi.org/10.1002/ jemt.1070220106

Publisher's note Springer Nature remains neutral with regard to jurisdictional claims in published maps and institutional affiliations. 